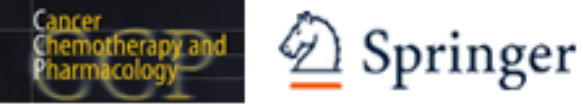

\title{
Do anthocyanins and anthocyanidins, cancer chemopreventive pigments in the diet, merit development as potential drugs?
}

\begin{tabular}{|r|l|}
\hline Journal: & Cancer Chemotherapy and Pharmacology \\
\hline Manuscript ID: & CCP-09-0052.R1 \\
\hline Manuscript Type: & Commentary \\
\hline Author: & 27-Feb-2009 \\
\hline & $\begin{array}{l}\text { Complete List of Authors: } \\
\text { Medicine } \\
\text { Mellecular Nicole; Universität Karlsruhe, Institute of Applied Biosciences } \\
\text { Marko, Doris; Universität Karlsruhe, Institute of Applied Biosciences } \\
\text { Berry, David; Leicester General Hospital, Department of } \\
\text { Hepatobiliary and Pancreatic Surgery } \\
\text { Steward, William; University of Leicester, Cancer Studies and } \\
\text { Molecular Medicine } \\
\text { Gescher, Andreas; Univ of Leicester, Cancer Studies and Molecular } \\
\text { medicine }\end{array}$ \\
\hline Keywords: & $\begin{array}{l}\text { anthocyanins, cancer chemoprevention , drug development, } \\
\text { stability }\end{array}$ \\
\hline
\end{tabular}

\section{S ScholaroNE


Commentary

\section{Do anthocyanins and anthocyanidins, cancer chemopreventive}

\section{pigments in the diet, merit development as potential drugs?}

Sarah Thomasset $\bullet$ Nicole Teller

Hong Cai $\bullet$ Doris Marko • David P Berry

William P Steward • Andreas J. Gescher

S. Thomasset $\cdot$ H. Cai $\cdot$ W.P. Steward $\cdot$ A.J. Gescher (correspondence)

Cancer Biomarkers and Prevention Group, Department of Cancer Studies and Molecular Medicine, RKCSB, LRI, University of Leicester, Leicester LE2 7LX, UK e-mail: ag15@le.ac.uk

N. Teller · D. Marko

Institute of Applied Biosciences, Section of Food Toxicology, Universität Karlsruhe (TH), Karlsruhe, Germany

D.P. Berry

Department of Hepatobiliary and Pancreatic Surgery, Leicester General Hospital, University Hospitals of Leicester, Leicester, UK

Running title: Anthocyanins and anthocyanidins: Potential drugs?

Keywords: cancer chemoprevention, anthocyanins, drug development 


\section{Abstract}

Anthocyanins, plant pigments in fruits and berries, have been shown to delay cancer development in rodent models of carcinogenesis, especially those of the colorectal tract. Anthocyanins and anthocyanidins, their aglycons, especially cyanidin and delphinidin, have been subjected to extensive mechanistic studies. In cells in vitro, both glycosides and aglycons engage an array of anti-oncogenic mechanisms including anti-proliferation, induction of apoptosis and inhibition of activities of oncogenic transcription factors and protein tyrosine kinases. Anthocyanins and anthocyanidins exist as four isomers, interconversion between which depends on $\mathrm{pH}$, temperature and access of light. Anthocyanidins are much more prone to avid chemical decomposition than the glycosides, and they only survive for minutes in the biophase. These pharmaceutical issues are very important determinants of the suitability of these flavonoids for potential development as cancer chemopreventive drugs, and they have hitherto not received adequate attention. In the light of their robust cancer chemopreventive efficacy in experimental models and their superior stability as compared to that of the aglycons, the anthocyanins seem much more suitable for further drug development than their anthocyanidin counterparts.

\section{Introduction}

Epidemiological studies suggest that consumption of certain diets, for example fruits, vegetables and fibre, can reduce the risk of developing cancer. Therefore in recent years the putative cancer chemopreventive properties of dietary constituents have become a focus of intense scrutiny. The search for efficacious and safe diet-derived alternatives to pharmaceuticals exemplified by aspirin, finasteride and tamoxifen, has been rendered even more relevant in the light of the realisation that diet constituents, 
in addition to delaying the onset of certain cancers, may also augment the efficacy of chemotherapeutic drugs in the treatment of established disease [1]. The plethora of published studies on mechanisms which may mediate chemopreventive or cochemotherapeutic effects of dietary constituents contrasts sharply with a dearth of information on their clinical pharmacological and pharmaceutical properties. Whilst such information is vital to help adjudge the suitability of developing them as potential drugs, it tends to attract insufficient attention by researchers in the field. Carried away by the enthusiasm generated by a particularly intriguing biochemical property in cells in vitro of the dietary component under study, they often conclude articles describing the novel mechanism to propose that the intervention in question "...could be developed as agent for the management of cancer...". Such statements are often premature, if not out of place, because pharmacological and pharmaceutical issues including stability, bioavailability and formulatability of the dietary constituent need to be taken into account before it can - even remotely - be considered for further drug development. This argument is particularly germane in the light of the precarious stability and bioavailability of many polyphenolic phytochemicals. The present review illustrates these issues focusing on anthocyanins, water-soluble pigments which occur abundantly in fruits and berries, and anthocyanidins, their aglycons. It summarizes the evidence for their cancer chemopreventive efficacy and juxtaposes it with their clinical pharmacology and pharmaceutical properties. The objective of the review is to highlight properties of this class of flavonoids which may define generic criteria applicable to the development of dietary agents. 


\section{Pharmaceutical properties}

The anthocyanins found most commonly in higher plants are the glycosides of the six anthocyanidins, with percentage abundance in brackets, cyanidin (50\%), pelargonidin (12\%), peonidin (12\%), delphinidin (12\%), petunidin (7\%) and malvidin (7\%) (Fig. 1) [2]. The most common sugar components of anthocyanins are glucose, galactose and arabinose, usually conjugated to the C3 hydroxyl group in the anthocyanidin $\mathrm{C}$ ring. To date, in excess of 400 naturally occurring anthocyanins have been identified [2].

The pharmaceutical Achilles heel of anthocyanidins and anthocyanins is their existence as several molecular forms in equilibrium with each other which depends highly on temperature, $\mathrm{pH}$ and presence of light and oxygen [3]. At $\mathrm{pH}<2$ a relatively stable flavylium cation predominates, responsible for the intense red colouration (Fig. $2 \mathrm{~A})$. Increasing $\mathrm{pH}$ is accompanied by rapid loss of a proton generating a blue quinoidal base. Hydration of the flavylium cation yields a colourless carbinol pseudobase. This species tautomerises, through opening of the C-ring, to generate a yellow chalcone (Fig. 2A). Both glycosides and aglycons can spontaneously degrade to a phenolic acid and phloroglucinol aldehyde (Fig. 2B), the latter probably via the intermediate trihydroxyphenyl acetaldehyde, both rather elusive species. The rate of breakdown differs dramatically between anthocyanins and their aglycons (vide infra).

The dosage forms in which anthocyanins have been administered in preclinical rodent experiments and clinical trials have been almost exclusively berry preparations, single agents have been administered in only a few studies. 


\section{Pharmacokinetics and metabolism}

ADME investigations have focussed almost exclusively on anthocyanin-rich plant products, i.e. naturally occurring mixtures of anthocyanins. Anthocyanins are rapidly absorbed and eliminated. Their bioavailability has been found to be consistently low across animal species including humans (reviewed in [3]). It is important to note two analytical chemical issues which complicate the interpretation of the ADME of anthocyanins and anthocyanidins. Firstly, species not absorbed in the upper gastrointestinal tract can be degraded and/or biotransformed by the gut microflora to furnish small phenolic aldehydes and acids undetectable by the analytical methods usually employed to measure anthocyanins or their aglycons [4]. Secondly, almost all analytical methods which have been used to measure these flavonoids involve acidification of biomatrix samples to transform species present at neutral $\mathrm{pH}$, i.e colourless carbinol pseudo-base and chalcone forms, into the flavylium cation (Fig. 2A). Metabolic conversion which impedes this conversion would result in failure to detect the analyte [5]. These issues illustrate that the clinical pharmacology of anthocyanins warrants much more study involving novel analytical approaches. Protocatechuic acid, generated from cyanidin-3-glucoside chemically and metabolically in the microflora, has recently been measured in human plasma at concentrations far in excess of the anthocyanin consumed as a constituent of Sicilian blood oranges [6]. However, formation in vivo of protocatechuic acid as a major cyanidin glycoside metabolite seems to be species-dependent, as it was not found in the biophase of rats on cyanidin-3-glucoside [7]. Glucuronidated and methylated conjugates are major metabolites of anthocyanins, and such species have been isolated from human urine and plasma [8,9]. Aglycones and sulphate conjugates have been identified as minor metabolites in human urine [10-12]. The presence of 
aglycones has also been demonstrated in jejunal tissue and plasma of rodents on oral anthocyanins [13] and, indirectly, in pigs which consumed a chokeberry extract. In the latter study identification of cyanidin monoglucuronide in the urine implied intermediate formation of the aglycon [14].

\section{Preclinical evidence for cancer chemopreventive properties}

Anthocyanins and anthocyanidins, predominantly in the form of mixtures, have demonstrated cancer chemopreventive properties in animal models of breast, skin, oesophageal, lung, oral and gastrointestinal carcinogenesis (Table 1). Evidence for efficacy is arguably most convincing for the latter, as illustrated by the following examples: Supplementation of the diet with $0.3 \%$ mirtocyan, a standardised bilberry extract containing 15 anthocyanins, caused about 30\% reduction in tumour number and burden in $A p c^{\mathrm{Min}}$ mice, a model of human familial adenomatous polyposis [15]. Isolated cyanidin-3-glucoside at that dose was similarly efficacious. This study identified anthocyanin concentrations in the blood and gastrointestinal tract associated with efficacy. An anthocyanin-rich extract derived from tart cherries reduced adenoma multiplicity but not size in this model [16]. In another study $A p c^{M i n}$ mice received either a mixture of anthocyanins or pure cyanidin in their drinking water at $800 \mathrm{mg} / \mathrm{l}$ or $200 \mathrm{mg} / \mathrm{l}$, respectively. A third group received dietary supplementation with $20 \%$ freeze-dried tart cherries [17]. The number and burden of caecal adenomas was reduced in all mice that received flavonoids compared to those that consumed a control diet, without an effect on small intestinal or colonic adenomas. Anthocyanins have also exhibited chemopreventive properties in chemically-induced models of colorectal carcinogenesis. Rats received 1,2 dimethylhydrazine (DMH) to induce colorectal 
adenomas and carcinomas followed by dietary supplementation (at 5\%) with extracts of purple corn, purple sweet potato or red cabbage and the carcinogen 2amino-1-methyl-6-phenylimidazopyridine (PhIP) which induces aberrant crypt foci (ACF) $[18,19]$. The average number of adenomas and adenocarcinomas was significantly reduced in rats which received flavonoids compared to controls. Induction of ACF by PhIP was significantly inhibited by purple corn and red cabbage colourings. Dietary supplementation with up to $10 \%$ lyophilized black raspberries significantly reduced azoxymethane-induced colorectal adenocarcinoma and ACF multiplicity in rats [20]. Anthocyanin-rich extracts of bilberry, chokeberry and grape also inhibited the development of ACF in this model [21]. Whilst all of this data strongly indicates chemopreventive efficacy of anthocyanins in rodent models of carcinogenesis, we know hardly anything about differences in potency in these models between individual anthocyanin molecules.

\section{Clinical evidence for cancer chemopreventive properties}

Anthocyanin-rich fruit or berry preparations have been investigated in healthy volunteers or individuals at high risk of developing cancer. Table 2 lists such studies and endpoints germane to cancer chemoprevention. Freeze-dried black raspberry gel was topically applied four times per day to 17 patients with oral intraepithelial neoplasia [22]. After 6 weeks pre- and post-treatment biopsies were evaluated for change in histopathology grade. Seven patients showed histopathological improvement, 6 exhibited stable disease and 4 evidence of progression. A reduction in loss of heterozygosity at tumour suppressor geneassociated loci was also observed. Loss of heterozygosity is linked to the development of many human cancers, including oral squamous cell carcinoma. 
There was an association, although relatively weak, between reduction in loss of heterozygosity and improvement in histopathology grade [22].

Trials of black raspberry powder are currently ongoing in patients with familial adenomatous polyposis who have undergone a subtotal colectomy with ileorectal anastomosis [23]. Over a period of 9 months patients take two black raspberry powder suppositories daily in combination with an oral dose of $20 \mathrm{~g}$ of black raspberry powder or placebo. Endoscopic biopsies are obtained at baseline, 18 weeks and 36 weeks. Preliminary data from 18 weeks suggests that consumption of this powder may be associated rectal polyp regression. Twenty patients with Barrett's oesophagus have been recruited into a trial of this berry preparation $[23,24]$. They consumed up to $45 \mathrm{~g}$ of black raspberry powder daily for 6 months. Endoscopic biopsies were obtained before and after treatment. Limited data to date suggests that the length of Barrett's lesions were unaltered by treatment. When urinary markers of oxidative stress were assessed, 8-epiprostaglandin F2a was significantly reduced, but there was no significant change in mean urinary levels of 8-oxo-7,8-dihydro-2'-deoxyguanosine.

Recently 25 patients with confirmed colorectal cancer received mirtocyan daily for 7 days before they underwent colectomy or resection of hepatic metastases [25]. Daily dose levels were equivalent to $0.5,1.0$ or $2.0 \mathrm{~g}$ of anthocyanins. Mirtocyan consumption caused a small decrease in proliferation and small increase in apoptosis in tumour tissue. Total levels of anthocyanins achieved in the biophase resembled those accompanying efficacious doses in the $A p c^{M i n}$ mouse [15] when doses were compared on the basis of body surface. 


\section{The case for anthocyanidins as potential drugs}

Anthocyanidins possess intriguing anticarcinogenic properties. They inhibit the growth of a range of tumour cells and induce apoptosis [26-33]. Delphinidin and cyanidin have been shown to inhibit the protein tyrosine kinase activity of the epidermal growth factor receptor and downstream events [33-36]. Anthocyanidins bearing methoxy moieties in the B-ring like malvidin interfered with 3',5'-cAMPspecific phosphodiesterase PDE4 [34]. Delphinidin induced apoptosis and inhibited $\mathrm{NF} K \mathrm{~B}$ signalling in prostate tumour cells in vitro and in a human prostate tumour xenograft in nude mice in vivo [26]. These findings have engendered the suggestion that delphinidin might be considered for development as potential anticancer agent. As intriguing as the mechanistic observations are, the suitability of this or other anthocyanidins for drug development needs to be interpreted in the light of their exquisite chemical instability, which confounds their clinical potential. In cell culture medium delphinidin and cyanidin broke down with half-lives of less than $30 \mathrm{~min}$, whilst the half lives of pelargonidin and peonidin were approximately an hour [32]. Furthermore, anthocyanidins generate hydrogen peroxide in cellular incubations, so that their cell growth-inhibitory efficacy in vitro may well have been the combined effect of a complicated mixture of phloroglucinol aldehyde, phenolic acid, hydrogen peroxide and parent compound. The stability of anthocyanidins in plasma and tissues has not been clearly defined, except that they broke down rapidly in the presence of intestinal microflora [37]. Anthocyanidins released locally from their glycosides have been suspected to mediate, at least in part, the efficacy of anthocyanins. Consistent with this notion formation of anthocyanidins from anthocyanins has been demonstrated in the biomatrix in vivo (vide supra), however 
at miniscule concentrations. Therefore it is possible, but not likely, that the anthocyanidins mediate the pharmacological effects of their parent glycosides.

\section{The case for anthocyanins as potential drugs}

Just like anthocyanidins, anthocyanins engage anticarcinogenic mechanisms in cells in vitro exemplified by interference with cell proliferation, induction of apoptosis, cell cycle arrest and antioxidation [38]. Anthocyanins have been shown to affect targets germane to oncogenesis such as AP-1, MAPK, NF- $\mathrm{kB}$, and COX-2, as illustrated by the properties of cyanidin-3-glucoside in A549 human lung tumour cells in vitro and in nude mouse bearing this tumour in vivo [39]. Mirtocyan at a concentration of 10 $\mu \mathrm{g} / \mathrm{ml}$ inhibited the receptor tyrosine kinases EGFR, ErbB2, ErbB3, VEGFR-2 and VEGFR-3 [40]. So the case for advocating anthocyanins for drug development on mechanistic grounds is similar to that for anthocyanidins.

Like their aglycons, anthocyanins are systemically poorly available, mainly due to exquisite susceptibility towards biotransformation. Where they differ is with respect to pharmaceutical properties. Anthocyanins are chemically more stable than anthocyanidins, as demonstrated under conditions of neutral $\mathrm{pH}$ [37], a fact which renders anthocyanins clearly superior candidates for drug development. The reason for the stability difference between aglycon and glycoside is the fact that the sugar moiety in the glycoside prevents or delays degradation of the $\alpha$-diketone intermediate to the phenolic acid and the aldehyde (Fig. 2B). In human plasma cyanidin- and delphinidin-3-glucosides were stable for $4 \mathrm{~h}$ at room temperature, and on long term storage at $-80^{\circ} \mathrm{C}$ for 2 months [41]. 


\section{Conclusion}

Existence as a mixture of isomers and propensity to undergo extensive metabolism are two properties which militate against the suitability of either anthocyanidins or anthocyanins for development as drugs. In the case of anthocyanidins their considerable chemical instability is an additional undesirable pharmaceutical property. The situation is different for anthocyanins. They survive under biophase conditions for an acceptable period of time. They engage anticarcinogenic mechanisms consistent with chemoprevention, and their robust chemopreventive activity in preclinical models advocates further studies. Anthocyanins are clearly superior to their aglycone counterparts as candidates for drug development. Should single anthocyanins or mixtures be developed? At this time not enough is known about differences in preclinical efficacy between individual anthocyanins to answer this question conclusively. If mixtures are to be developed, the appropriate strategy to determine anthocyanin pharmacokinetics needs careful planning. For example, need all constituents of a mixture including metabolites generated from them to be quantitated, or is it sufficient to measure representative anthocyanins? Future studies have to resolve these questions. Standardized mixtures of anthocyanins fit for human consumption are commercially available for study now. Such mixtures tend to contain constituents of the fruit source other than anthocyanins, which may also contribute to chemopreventive efficacy.

Acknowledgement The work in the Karlsruhe and Leicester groups is supported by a grant from the FlavoNet initiative of the Deutsche Forschungsgemeinschaft and a programme grant from Cancer Research UK. 


\section{Conflict of interest disclosures: None}

\section{References}

1. D'Incalci MC, Steward WP, Gescher AJ (2005) Use of cancer chemopreventive phytochemicals as antineoplastic agents. Lancet Oncol 6: 899-904.

2. Kong JM, Chia LS, Goh NK, et al (2003) Analysis and biological activities of anthocyanins. Phytochemistry 64: 923-933.

3. McGhie TK, Walton MC (2007) The bioavailability and absorption of anthocyanins: Towards a better understanding. Mol Nutr Food Res 51: 702-713.

4. Aura AM, Martin-Lopez P, O'Leary KA, et al (2005) In vitro metabolism of anthocyanins by human gut microflora. Eur J Nutr 44: 133-142.

5. McGhie TK, Ainge GD, Barnett LE, et al (2003) Anthocyanin glycosides from berry fruit are absorbed and excreted unmetabolized by both humans and rats. J Agric Food Chem 51: 4539-4548.

6. Vitaglione P, Donnarumma G, Napolitano A, et al (2007) Protocatechuic acid is the major human metabolite of cyanidin-glucosides. J Nutr 137: 2043-2048.

7. Ichiyanagi T RM, Hatano Y, Konishi T, et al (2007) Protocatechuic acid is not the major metabolite in rat blood plasma after oral administration of cyanidin 3-O-beta-Dglucopyranoside. Food Chem 105: 1032-1039.

8. Kay CD, Mazza G, Holub BJ, et al (2004) Anthocyanin metabolites in human urine and serum. Br J Nutr 91: 933-942.

9. Kay CD, Mazza GJ, Holub BJ (2005) Anthocyanins exist in the circulation primarily as metabolites in adult men. J Nutr 135: 2582-2588. 
10. Felgines C, Talavera S, Texier O, et al (2005) Blackberry anthocyanins are mainly recovered from urine as methylated and glucuronidated conjugates in humans. J Agric Food Chem 53: 7721-727.

11. Felgines C, Talavera S, Gonthier MP, et al (2003) Strawberry anthocyanins are recovered in urine as glucuro- and sulfoconjugates in humans. J Nutr 133: 12961301.

12. Mullen W, Edwards CA, Serafini M, et al (2008) Bioavailability of pelargonidin-3O-glucoside and its metabolites in humans following the ingestion of strawberries with and without cream. J Agric Food Chem 56: 713-719.

13. Talavera S, Felgines C, Texier O, et al (2005) Anthocyanin metabolism in rats and their distribution to digestive area, kidney, and brain. J Agric Food Chem 53: 3902-3908.

14. Wu X, Pittman HE, McKay S, et al (2005) Aglycones and sugar moieties alter anthocyanin absorption and metabolism after berry consumption in weanling pigs. $\mathrm{J}$ Nutr 135:2417-2424.

15. Cooke D, Schwarz M, Boocock D, et al (2006) Effect of cyanidin-3-glucoside and an anthocyanin mixture from bilberry on adenoma development in the ApcMin mouse model of intestinal carcinogenesis--relationship with tissue anthocyanin levels. Int J Cancer 119: 2213-2220.

16. Bobe G, Wang B, Seeram NP, et al (2006) Dietary anthocyanin-rich tart cherry extract inhibits intestinal tumorigenesis in APC(Min) mice fed suboptimal levels of sulindac. J Agric Food Chem 54: 9322-9328.

17. Kang SY, Seeram NP, Nair MG, et al (2003) Tart cherry anthocyanins inhibit tumor development in $\mathrm{Apc}(\mathrm{Min})$ mice and reduce proliferation of human colon cancer cells. Cancer Lett 194: 13-19. 
18. Hagiwara A, Miyashita K, Nakanishi T, et al (2001) Pronounced inhibition by a natural anthocyanin, purple corn color, of 2-amino-1-methyl-6-phenylimidazo[4,5b]pyridine (PhIP)-associated colorectal carcinogenesis in male F344 rats pretreated with 1,2-dimethylhydrazine. Cancer Lett 171: 17-25.

19. Hagiwara A, Yoshino $H$, Ichihara $T$, et al (2002) Prevention by natural food anthocyanins, purple sweet potato color and red cabbage color, of 2-amino-1methyl-6-phenylimidazo[4,5-b]pyridine (PhIP)-associated colorectal carcinogenesis in rats initiated with 1,2-dimethylhydrazine. J Toxicol Sci 27: 57-68.

20. Harris GK, Gupta A, Nines RG, et al (2001) Effects of lyophilized black raspberries on azoxymethane-induced colon cancer and 8-hydroxy-2'deoxyguanosine levels in the Fischer 344 rat. Nutr Cancer 40:125-133.

21. Lala G, Malik M, Zhao C, et al (2006) Anthocyanin-rich extracts inhibit multiple biomarkers of colon cancer in rats. Nutr Cancer 54: 84-93.

22. Shumway BS, Kresty LA, Larsen PE, et al (2008) Effects of a topically applied bioadhesive berry gel on loss of heterozygosity indices in premalignant oral lesions. Clin Cancer Res 14: 2421-2430.

23. Stoner GD, Wang LS, Zikri N, et al (2007) Cancer prevention with freeze-dried berries and berry components. Semin Cancer Biol 17: 403-410.

24. Kresty LA, Frankel WL, Hammond CD, et al (2006) Transitioning from preclinical to clinical chemopreventive assessments of lyophilized black raspberries: interim results show berries modulate markers of oxidative stress in Barrett's esophagus patients. Nutr Cancer 54: 148-156.

25. Thomasset S, Berry DP, Cai H, et al (2009) Pilot study of oral anthocyanins for colorectal cancer chemoprevention. Cancer Prev Res, in press. 
26. Hafeez BB SI, Asim M, Malik A, et al (2008) A dietary anthocyanidin delphinidin induces apoptosis of human prostate cancer PC3 cells in vitro and in vivo: involvement of nuclear factor-kB signaling. Cancer Res 68: 8564-8572. 27. Shih PH, Yeh CT, Yen GC (2005) Effects of anthocyanidin on the inhibition of proliferation and induction of apoptosis in human gastric adenocarcinoma cells. Food Chem Toxicol 43: 1557-1566.

28. Hyun JW, Chung HS (2004) Cyanidin and Malvidin from Oryza sativa cv. Heugjinjubyeo mediate cytotoxicity against human monocytic leukemia cells by arrest of G(2)/M phase and induction of apoptosis. J Agric Food Chem 52: 22132217.

29. Katsube N, Iwashita K, Tsushida T, et al (2003) Induction of apoptosis in cancer cells by Bilberry (Vaccinium myrtillus) and the anthocyanins. J Agric Food Chem 51: 68-75.

30. Syed DN, Afaq F, Sarfaraz S, et al (2008) Delphinidin inhibits cell proliferation and invasion via modulation of Met receptor phosphorylation Toxicol Appl Pharmacol 231: 52-60.

31. Zhao C, Giusti MM, Malik M, Moyer MP, Magnuson BA (2004) Effects of commercial anthocyanin rich extracts on colonic cancer and nontumorigenic colon cell growth. J Agric Food Chem 52: 6122-6128.

32. Kern M, Fridrich D, Reichert J, et al (2007) Limited stability in cell culture medium and hydrogen peroxide formation affect the growth inhibitory properties of delphinidin and its degradation product gallic acid. Mol Nutr Food Res 51: 1163-1172.

33. Meiers S, Kemény M, Weyand U, Gastpar R, von Angerer E, Marko D (2001) The anthocyanidins cyanidin and delphinidin are potent inhibitors of the epidermal growth-factor receptor. J Agric Food Chem 49: 958-962. 
34. Marko D, Puppel N, Tjaden Z, et al (2004) The substitution pattern of anthocyanidins affects different cellular signaling cascades regulating cell proliferation. Mol Nutr Food Res 48: 318-325.

35. Fridrich D, Teller N, Esselen M, et al (2008) Comparison of delphinidin, quercetin and (-)-epigallocatechin-3-gallate as inhibitors of the EGFR and the ErbB2 receptor phosphorylation. Mol Nutr Food Res 52: 815-822.

36. Afaq F, Zaman N, Khan N, et al (2008) Inhibition of epidermal growth factor receptor signaling pathway by delphinidin, an anthocyanidin in pigmented fruits and vegetables. Int J Cancer 123: 1508-1515.

37. Fleschhut J KF, Rechkemmer G, Kulling SE (2006) Stability and biotransformation of various dietary anthocyanins in vitro. Eur J Nutr 45: 7-18.

38. Cooke D, Steward WP, Gescher AJ, et al (2005) Anthocyans from fruits and vegetables-does bright colour signal cancer chemopreventive activity? Eur J Cancer 41: 1931-1940.

39. Ding M, Feng R, Wang SY, et al (2006) Cyanidin-3-glucoside, a natural product derived from blackberry, exhibits chemopreventive and chemotherapeutic activity. $J$ Biol Chem 281: 17359-17368.

40. Teller N, Thiele W, Marczylo TH, et al (2009) Impact of anthocyanin-rich mixtures extracted from bilberries and grapes on receptor tyrosine kinases. J Agr Food Chem, in press.

41. Giordano L CW, Rapisarda P, Donati MB, et al (2007) Development and validation of an LC-MS/MS analysis for simultaneous determination of delphinidin-3glucoside, cyanidin-3-glucoside and cyanidin-3-(6-malonylglucoside) in human plasma and urine after blood orange juice administration. J Sep Sci 30: 3127-3136. 42. Singletary KW, Stansbury MJ, Giusti M, et al (2003) Inhibition of rat mammary tumorigenesis by Concord grape juice constituents. J Agric Food Chem 51: 72807286. 
43. Jung KJ, Wallig MA, Singletary KW (2006) Purple grape juice inhibits 7,12dimethylbenz[a]anthracene (DMBA)-induced rat mammary tumorigenesis and in vivo DMBA-DNA adduct formation. Cancer Lett 233: 279-288.

44. Kim JM, Kim JS, Yoo H, et al (2008) Effects of black soybean [Glycine max (L) Merr] seed coats and its anthocyanidins on colonic inflammation and cell proliferation in vitro and in vivo. J Agric Food Chem 56: 8427-8433

45. Carlton PS, Kresty LA, Stoner GD (2000) Failure of dietary lyophilized strawberries to inhibit 4-(methylnitrosamino)-1-butanone and benzo[a]pyreneinduced lung tumorigenesis in strain A/J mice. Cancer Lett 159: 113-117. 46. Stoner GD, Kresty LA, Carlton PS (1999) Isothiocyanates and freeze-dried strawberries as inhibitors of esophageal cancer. Toxicol Sci 52S: 95-100.

47. Carlton PS, Kresty LA, Siglin JC, et al (2001) Inhibition of Nnitrosomethylbenzylamine-induced tumorigenesis in the rat esophagus by dietary freeze-dried strawberries. Carcinogenesis 22: 441-446.

48. Kresty LA, Morse MA, Morgan C, et al (2001) Chemoprevention of esophageal tumorigenesis by dietary administration of lyophilized black raspberries. Cancer Res 61: 6112-6119.

49. Aziz RM, Nines R, Rodrigo K, et al (2002) The effect of freeze-dried blueberries on $\mathrm{N}$-nitrosmethylbenzylamine tumorigenesis in the rat esophagus. Pharmaceut Biol 40S:43-49.

50. Chen T, Hwang H, Rose ME, et al (2006) Chemopreventive properties of black raspberries in $\mathrm{N}$-nitrosomethylbenzylamine-induced rat esophageal tumorigenesis: Down-regulation of cyclooxygenase-2, inducible nitric oxide synthase, and c-Jun. Cancer Res 66: 2853-2859. 
51. Chen $\mathrm{T}$, Rose ME, Hwang $\mathrm{H}$, et al (2006) Black raspberries inhibit $\mathrm{N}$ nitrosomethylbenzylamine (NMBA)-induced angiogenesis in rat esophagus parallel to the suppression of COX-2 and iNOS. Carcinogenesis 27: 2301-2307.

52. Stoner GD, Aziz RM (2007) Prevention and therapy of squamous cell carcinoma of the rodent esophagus using freeze-dried black raspberries. Acta Pharmacol Sin 28: $1422-1428$.

53. Lechner JF, Reen RK, Dombkowski AA, et al (2008) Effects of a black raspberry diet on gene expression in the rat esophagus. Nutr Cancer 60: 61-69.

54. Stoner GD, Dombkowski AA, Reen RK, et al (2008) Carcinogen-altered genes in the rat esophagus positively modulated to normal levels of expression by both black raspberries and phenylethyl isothiocyanate. Cancer Res 68: 6460-6467.

55. Wang LS, Hecht SS, Carmella SG, et al (2009) Anthocyanins in black raspberries prevent esophageal tumors in rats. Cancer Prev Res 2:84-93.

56. Casto BC, Kresty LA, Kraly CL, et al (2002) Chemoprevention of oral cancer by black raspberries. Anticancer Res 22: 4005-4015.

57. Bomser JA, Singletary KW, Wallig MA, et al (1999) Inhibition of TPA-induced tumor promotion in CD-1 mouse epidermis by a polyphenolic fraction from grape seeds. Cancer Lett 135:151-157.

58. Afaq F, Saleem M, Krueger CG, et al (2005) Anthocyanin- and hydrolyzable tannin-rich pomegranate fruit extract modulates MAPK and NF-kappaB pathways and inhibits skin tumorigenesis in CD-1 mice. Int J Cancer 113: 423-433.

59. Afaq F, Syed DN, Malik A, et al (2007) Delphinidin, an anthocyanidin in pigmented fruits and vegetables, protects human $\mathrm{HaCaT}$ keratinocytes and mouse skin against UVB-mediated oxidative stress and apoptosis. J Invest Dermatol 127: 222-232 
60. Lamy S, Beaulieu E, Labbe D, et al (2008) Delphinidin, a dietary anthocyanidin, inhibits platelet-derived growth factor ligand/receptor (PDGF/PDGFR) signalling. Carcinogenesis 29: 1033-1041

61. Chen PN, Chu SC, Chiou HL, et al (2005) Cyanidin 3-glucoside and peonidin 3glucoside inhibit tumor cell growth and induce apoptosis in vitro and suppress tumor growth in vivo. Nutr Cancer 53: 232-243.

62. Koide T, Kamei H, Hashimoto Y, et al (1996) Antitumor effect of hydroylsed anthocyanin from grape rinds and red rice. Cancer Biother Radiopharm 11: 273-277. 63. Cao G, Russell RM, Lischner N, et al (1998) Serum antioxidant capacity is increased by consumption of strawberries, spinach, red wine or vitamin $C$ in elderly women. J Nutr 128: 2383-2390.

64. Mazza G, Kay CD, Cottrell T, et al (2002) Absorption of anthocyanins from blueberries and serum antioxidant status in human subjects. J Agric Food Chem 50: 7731-7737.

65. Matsumoto H, Nakamura Y, Hirayama M, et al (2002) Antioxidant activity of black currant anthocyanin aglycons and their glycosides measured by chemiluminescence in a neutral pH region and in human plasma. J Agric Food Chem 50: 5034-5037.

66. Kay CD, Holub BJ (2002) The effect of wild blueberry (Vaccinium angustifolium) consumption on postprandial serum antioxidant status in human subjects. $\mathrm{Br} \mathrm{J}$ Nutr 88: 389-398.

67. Chung MJ, Lee SH, Sung NJ (2002) Inhibitory effect of whole strawberries, garlic juice or kale juice on endogenous formation of $\mathrm{N}$-nitrosodimethylamine in humans. Cancer Lett 182: 1-10.

68. Bub A, Watzl B, Blockhaus M, et al (2003) Fruit juice consumption modulates antioxidative status, immune status and DNA damage. J Nutr Biochem 14: 90-98. 
69. Moller P, Loft S, Alfthan G, et al (2004) Oxidative DNA damage in circulating mononuclear blood cells after ingestion of blackcurrant juice or anthocyanin-rich drink. Mutation Res 551:119-126.

70. Riso P, Visioli F, Gardana C, et al (2005) Effects of blood orange juice intake on antioxidant bioavailability and on different markers related to oxidative stress. J Agric Food Chem 53: 941-947.

71. Weisel T, Baum M, Eisenbrand G, et al (2006) An anthocyanin/polyphenolic-rich fruit juice reduces oxidative DNA damage and increases glutathione level in healthy probands. Biotechnol J 1: 388-397.

72. Duthie SJ, Jenkinson AM, Crozier A, et al (2006) The effects of cranberry juice consumption on antioxidant status and biomarkers relating to heart disease and cancer in healthy human volunteers. Eur J Nutr 45: 113-122.

73. Mertens-Talcott SU, Rios J, Jilma-Stohlawetz P, et al (2008) Pharmacokinetics of anthocyanins and antioxidant effects after the consumption of anthocyanin-rich acai juice and pulp (Euterpe oleracea Mart.) in human healthy volunteers. J Agric Food Chem 56: 7796-7802.

74. Jensen GS, Wu X, Patterson KM, et al (2008) In vitro and in vivo anthioxidant and anti-inflammatory capacities of an antioxidant-rich fruit and berry juice blend. Results of a pilot and randomised, double-blinded, placebo-controlled crossover study. J Agric Food Chem 56: 8326-8333.

75. Mallery SR, Zwick JC, Pei P, et al (2008) Topical application of a bioadhesive black raspberry gel modulates gene expression and reduces cyclooxygenase 2 protein in human premalignant oral lesions. Cancer Res 68: 4945-4957. 
76. Spormann TM, Albert FW, Rath T, et al (2008) Anthocyanin/polyphenolic-rich fruit juice reduces oxidative cell damage in an intervention study with patients on hemodialysis. Cancer Epidemiol Biomarkers \& Prev 7:3372-3380.

\section{Figure legends}

Fig. 1 Structure of anthocyanidins and anthocyanins.

Fig. 2 Molecular forms (A) and decomposition products (B) of anthocyanins and anthocyanidins, exemplified by cyanidin glycoside ( $R=$ sugar) and cyanidin $(R=H)$ [37]. 
Table 1: Chemopreventive efficacy of anthocyanins/anthocyanidins in animal models of carcinogenesis

\begin{tabular}{|c|c|c|c|c|}
\hline Model & Anthocyanin preparation & $\begin{array}{l}\text { Anthocyanin dose } \\
\text { (\% diet, wt } / w t)^{*}\end{array}$ & $\begin{array}{l}\text { Length of treatment } \\
\text { (weeks) }{ }^{*}\end{array}$ & Primary outcomes \\
\hline $\begin{array}{l}\text { Breast, DMBA-treated rats } \\
\text { [42] }\end{array}$ & Grape juice & $\begin{array}{l}\text { Up to } 781 \mathrm{mg} / \mathrm{L} \text { drinking } \\
\text { water }\end{array}$ & 20 & $\begin{array}{l}\downarrow \text { Tumour incidence weeks } 9 \text { and } 10^{\dagger} \\
\downarrow \text { Final tumour mass }\end{array}$ \\
\hline $\begin{array}{l}\text { Breast, DMBA-treated rats } \\
\text { [43] }\end{array}$ & Grape juice & $\begin{array}{l}\text { Up to } 830 \mathrm{mg} / \mathrm{L} \text { drinking } \\
\text { water }\end{array}$ & 3 & $\begin{array}{l}\leftrightarrow \text { Tumour incidence } \\
\downarrow \text { Final tumour mass } \\
\downarrow \text { DMBA-DNA adducts (mammary \& } \text { liver }^{\dagger} \text { ) } \\
\downarrow \text { 8-oxo-dG (mammary) } \\
\leftrightarrow \text { 8-oxo-dG (liver) }\end{array}$ \\
\hline \multirow[t]{3}{*}{$\begin{array}{l}\text { Colorectum, } A p c^{\mathrm{Min}} \text { mice } \\
\text { [17] }\end{array}$} & Tart cherry extract & $\begin{array}{l}800 \mathrm{mg} / \mathrm{L} \text { drinking } \\
\text { water }\end{array}$ & 10 & $\begin{array}{l}\downarrow \text { Adenoma number and volume (caecum) } \\
\leftrightarrow \text { Adenoma number (colon/small } \\
\text { intestine) }\end{array}$ \\
\hline & Cyanidin & $\begin{array}{l}200 \mathrm{mg} / \mathrm{L} \text { drinking } \\
\text { water }\end{array}$ & 10 & $\begin{array}{l}\downarrow \text { Adenoma number and volume (caecum) } \\
\leftrightarrow \text { Adenoma number (colon/small } \\
\text { intestine) }\end{array}$ \\
\hline & $\begin{array}{l}\text { Freeze-dried ground tart } \\
\text { cherries }\end{array}$ & $0.008-0.02$ & 10 & $\begin{array}{l}\downarrow \text { Adenoma number and volume (caecum) } \\
\leftrightarrow \text { Adenoma number (colon/small } \\
\text { intestine) }\end{array}$ \\
\hline \multirow[t]{2}{*}{$\begin{array}{l}\text { Colorectum, } A p c^{\mathrm{Min}} \text { mice } \\
\text { [15] }\end{array}$} & Cyanidin-3-glucoside & Up to 0.3 & 12 & $\begin{array}{l}\downarrow \text { Adenoma number (intestine) }{ }^{\dagger} \\
\downarrow \mathrm{M}_{1} \mathrm{dG} \text { (adenomas) }\end{array}$ \\
\hline & Bilberry extract & Up to 0.1 & 12 & $\begin{array}{l}\downarrow \text { Adenoma number (intestine) } \\
\downarrow \mathrm{M}_{1} \mathrm{dG} \text { (adenomas) }\end{array}$ \\
\hline $\begin{array}{l}\text { Colorectum, } A p c^{\mathrm{Min}} \text { mice } \\
{[16]}\end{array}$ & Tart cherry extract & $\begin{array}{l}\text { Up to } 0.3 \\
+0.01 \text { sulindac }\end{array}$ & 19 & $\begin{array}{l}\downarrow \text { Adenoma number (small intestine) })^{\ddagger} \\
\downarrow \text { Adenoma area (small intestine) } \\
\leftrightarrow \text { Adenoma size (small intestine) })^{\ddagger}\end{array}$ \\
\hline
\end{tabular}


Colorectum,

azoxymethane-treated rats [20]

\section{Colorectum}

azoxymethane-treated rats [21]

\section{Freeze-dried black}

Up to 0.2

33

raspberries

Chokeberry extract

0.4

14

Bilberry extract

Grape extract

0.006

Colorectum,

Black soybean

[44]

Colorectum, DMH-and

PhIP-treated rats [18]
Purple corn colour

1.1 $\downarrow$ Aberrant crypt foci (colon)

$\downarrow$ Tumour number (colon)

$\downarrow$ Mean tumour burden (colon) ${ }^{\diamond}$

$\downarrow$ 8-oxo-dG (urine)

$\downarrow$ Aberrant crypt foci (colon)

$\leftrightarrow$ 8-oxo-dG (urine)

$\leftrightarrow$ COX-2 mRNA (colon)

$\downarrow$ PCNA (colon)

$\downarrow$ Aberrant crypt foci (colon)

$\leftrightarrow$ 8-oxo-dG (urine)

$\downarrow$ COX-2 mRNA (colon)

$\downarrow$ PCNA (colon)

$\downarrow$ Aberrant crypt foci (colon) $\leftrightarrow 8$-oxo-dG (urine)

$\downarrow$ COX-2 mRNA (colon)

$\leftrightarrow$ PCNA (colon)

$\downarrow$ Aberrant crypt foci (colon) ${ }^{\diamond}$

$\downarrow$ COX-2 mRNA (colon)

$\downarrow \mathrm{PGE}_{2}$ (plasma)

$\downarrow$ Aberrant crypt foci (colon)

$\downarrow$ Adenoma number (colon)

$\downarrow$ Adenocarcinoma number (colon)

$\leftrightarrow$ Extra-colonic tumours 
Colorectum, $\mathrm{DMH}$ - and

PhIP-treated rats [19]

\author{
treated rats [47] \\ Oesophagus, NMBA- \\ treated rats [48] \\ Lung, NNK- and B[a]P- \\ treated mice [45] \\ Oesophagus, NMBA- \\ treated rats [46]
}

Oesophagus, NMBAtreated rats [49]
Purple sweet potato colour

2.5

32

Red cabbage colour

32

Freeze-dried strawberries Not reported

Not reported

Freeze-dried strawberries

(

Not reported

Not reported raspberries

Freeze-dried blueberries

Not reported $\leftrightarrow$ Aberrant crypt foci (colon)

$\downarrow$ Adenoma number (colon)

$\leftrightarrow$ Adenocarcinoma number (colon)

$\leftrightarrow$ Extra-colonic tumours

$\downarrow$ Aberrant crypt foci (colon)

$\downarrow$ Adenoma number (colon)

$\downarrow$ Adenocarcinoma number (colon)

$\leftrightarrow$ Extra-colonic tumours

$\leftrightarrow$ Tumour incidence or multiplicity

$\leftrightarrow$ Papilloma incidence

$\downarrow$ Tumour multiplicity

$\downarrow 0^{6}$-methylguanine adduct (oesophagus)

$\leftrightarrow$ Tumour incidence

$\downarrow$ Tumour multiplicity

$\downarrow \mathrm{O}^{6}$-methylguanine adduct (oesophagus)

$\downarrow$ Tumour incidence

$\downarrow$ Tumour multiplicity

$\leftrightarrow$ Tumour size

$\downarrow 0^{6}$-methylguanine adduct

(oesophagus) $^{\dagger}$

$\leftrightarrow$ Tumour incidence

$\leftrightarrow$ Tumour multiplicity

$\downarrow$ Tumour size

$\downarrow 0^{6}$-methylguanine adduct (oesophagus) 
Oesophagus, NMBAtreated rats [50]

Oesophagus, NMBAtreated rats [51]

Oesophagus, NMBAtreated rats [52]

Oesophagus, NMBAtreated rats [53]

Oesophagus, NMBAtreated rats [54]

Oesophagus, NMBAtreated rats [55]

Oral malignancy, DMBAtreated hamsters [56]
Freeze-dried black raspberries

0.3

25

Freeze-dried black raspberries

Freeze-dried black raspberries

Freeze-dried black raspberries

Freeze-dried black raspberries

Freeze-dried black raspberry powder/extract

Freeze-dried black raspberries
Not reported

Not reported

Not reported

Not reported

Not reported

30

Not reported $\downarrow$ Tumour incidence ${ }^{\diamond}$

$\downarrow$ Tumour multiplicity

$\leftrightarrow$ Tumour volume

$\downarrow$ C-Jun (preneoplastic lesions, papillomas)

$\downarrow$ i-NOS (preneoplastic lesions, papillomas )

$\downarrow$ COX-2 (preneoplastic lesions)

$\leftrightarrow \mathrm{COX}-2$ (papillomas)

$\downarrow$ VEGF-C (oesophagus)

$\downarrow$ Microvessel density (oesophagus)

$\leftrightarrow$ Tumour incidence

$\leftrightarrow$ Tumour multiplicity

$\leftrightarrow$ Tumour volume

$\uparrow$ Survival

$\uparrow$ Expression of 24 genes (oesophagus)

$\downarrow$ Expression of 12 genes (oesophagus)

Restoration of 462 of 2,261 NMBA-

dysregulated genes to near-normal levels (oesophagus)

$\downarrow$ Tumour number

$\downarrow$ Tumour burden

$\leftrightarrow$ Tumour size

$\downarrow$ Tumour multiplicity $^{\dagger}$

$\downarrow$ DNA adducts (cheek pouches) 


\begin{tabular}{|c|c|c|c|c|}
\hline \multirow[t]{2}{*}{$\begin{array}{l}\text { Skin, TPA- and DMBA- } \\
\text { treated mice [57] }\end{array}$} & $\begin{array}{l}\text { Grape seed polyphenols } \\
\text { (GSP) }\end{array}$ & $\begin{array}{l}\text { Not reported } \\
\text { Up to } 30 \mathrm{mg} \text { GSP } \\
\text { topical }\end{array}$ & 1 dose & $\begin{array}{l}\downarrow \text { ODC activity (skin) } \\
\downarrow \text { MPO activity (skin) }\end{array}$ \\
\hline & & $\begin{array}{l}\text { Up to } 20 \mathrm{mg} \text { GSP } \\
\text { topical, twice/week }\end{array}$ & 15 & $\begin{array}{l}\downarrow \text { Tumour incidence } \\
\downarrow \text { Tumour multiplicity }\end{array}$ \\
\hline $\begin{array}{l}\text { Skin, TPA- and DMBA- } \\
\text { treated mice [58] }\end{array}$ & Pomegranate extract & $\begin{array}{l}\text { Not reported } \\
2 \text { mg of extract topical, } \\
\text { up to twice/week }\end{array}$ & Up to 30 & $\begin{array}{l}\downarrow \text { Tumour number } \\
\downarrow \text { Epidermal hyperplasia } \\
\downarrow \text { ODC expression (skin) } \\
\downarrow \text { COX-2 expression (skin) } \\
\downarrow \text { Phosphorylation of MAPKs (skin) }\end{array}$ \\
\hline $\begin{array}{l}\text { Skin, TPA- and DMBA- } \\
\text { treated mice [39] }\end{array}$ & Cyanidin-3-glucoside & $\begin{array}{l}3.5 \mu \mathrm{M} \text { topical, } \\
\text { twice/week }\end{array}$ & 21 & $\begin{array}{l}\downarrow \text { Tumour number } \\
\downarrow \text { Tumour size }\end{array}$ \\
\hline $\begin{array}{l}\text { Skin, UVB-treated mice } \\
\text { [59] }\end{array}$ & Delphinidin & $1 \mathrm{mg}$ topical & 1 dose & $\begin{array}{l}\downarrow \text { Cyclobutane pyrimidine dimers (skin) } \\
\downarrow \text { 8-oxo-dG (skin) } \\
\downarrow \text { apoptosis, TUNEL assay (skin) }\end{array}$ \\
\hline $\begin{array}{l}\text { Xenograft, A549 human } \\
\text { lung carcinoma cells in } \\
\text { mice [39] }\end{array}$ & Cyanidin-3-glucoside & $\begin{array}{l}9.5 \mathrm{mg} / \mathrm{kg} \\
\text { intraperitoneal, } \\
\text { three times/week }\end{array}$ & 5 & $\begin{array}{l}\downarrow \text { Xenograft growth } \\
\downarrow \text { Metastases }\end{array}$ \\
\hline $\begin{array}{l}\text { Xenograft, LLC murine } \\
\text { lung carcinoma cells in } \\
\text { mice } 611]\end{array}$ & Black rice anthocyanins & 0.5 oral gavage & 30 days & $\begin{array}{l}\downarrow \text { Tumour volume } \\
\downarrow \text { Tumour weight }\end{array}$ \\
\hline
\end{tabular}




\begin{tabular}{|c|c|c|c|c|}
\hline $\begin{array}{l}\text { Xenograft, PC3 human } \\
\text { prostate carcinoma cells in } \\
\text { mice [26] }\end{array}$ & Delphinidin & $\begin{array}{l}2 \mathrm{mg} \text { intraperitoneal, } \\
\text { three times/week }\end{array}$ & 12 & $\begin{array}{l}\downarrow \text { Tumour volume } \\
\downarrow \text { Bcl2 (tumour) } \\
\uparrow \text { Bax (tumour) } \\
\downarrow \text { NF-KB (tumour) } \\
\downarrow \text { Cyclin D1 (tumour) } \\
\downarrow \text { Ki-67 and PNCA (tumour) }\end{array}$ \\
\hline $\begin{array}{l}\text { Xenograft, Meth/A murine } \\
\text { lymphoma cells in mice } \\
\text { [62] }\end{array}$ & Red rice & Not reported & 30 days & $\uparrow$ Survival \\
\hline
\end{tabular}

8-oxo-dG, 8-hydroxyguanosine; B[a]P, benzo[a]pyrene; COX-2, cyclooxygenase-2; DMBA, 7,12-dimethylbenz(a)anthracene; DMH, 1,2dimethylhydrazine; i-NOS, inducible nitrogen oxide; LLC, Lewis lung carcinoma; $\mathrm{M}_{1} \mathrm{dG}$, malondialdehyde DNA adduct; MAPK, mitogen-activated protein kinase; MPO, myeloperoxidase; NF-KB, nuclear factor-kB; NMBA, N-nitrosomethylbenzylamine; NNK, 4-(methylnitrosamino)-1-(3-pyridyl)1-butanone; ODC, ornithine decarboxylase; PCNA, proliferating cell nuclear antigen; PhIP, 2-amino-1-methyl-6-phenylimidazo[4,5-b]pyridine; ODC, ornithine decarboxylase; TPA, 12-O-tetradecanolylphorbol-13-acetate; TUNEL, terminal deoxynucleotidyl transferase mediated dUTP nickend label.

${ }^{*}$ Unless specified otherwise. Statistically significant $(p<0.05)$ at ${ }^{\dagger}$ certain doses or ${ }^{\ddagger}$ when all doses are combined. ${ }^{\diamond}$ Not statistically significant. $\uparrow$ Increase, $\downarrow$ Decrease, $\leftrightarrow$ Unchanged. 


\section{Table 2: Chemoprevention pharmacodynamic studies of anthocyanins in humans}

\begin{tabular}{|c|c|c|c|c|}
\hline Study participants & Anthocyanin preparation & $\begin{array}{l}\text { Anthocyanin dose } \\
(\mathrm{mg})^{*}\end{array}$ & $\begin{array}{l}\text { Treatment duration } \\
\text { (weeks) }^{*}\end{array}$ & Primary outcome \\
\hline \multirow[t]{2}{*}{ Healthy volunteers [63] } & Strawberries & Not reported & 1 dose & $\begin{array}{l}\uparrow \text { Serum antioxidant capacity (ORAC, } \\
\text { FRAP, TEAC }{ }^{\diamond} \text { ) } \\
\uparrow \text { Urine antioxidant capacity (ORAC) }\end{array}$ \\
\hline & Lyophilized red wine & Not reported & 1 dose & $\begin{array}{l}\uparrow \text { Serum antioxidant capacity (ORAC, } \\
\text { FRAP, TEAC }{ }^{\diamond} \text { ) } \\
\uparrow \text { Urine antioxidant capacity (ORAC) }\end{array}$ \\
\hline Healthy volunteers [64] & $\begin{array}{l}\text { Freeze-dried blueberry } \\
\text { powder }\end{array}$ & 1200 & 1 dose & $\begin{array}{l}\uparrow \text { Serum antioxidant capacity }\left(\mathrm{ORAC}^{\dagger} \text {, }\right. \\
\text { TEAC }^{\natural} \text { ) }\end{array}$ \\
\hline Healthy volunteers [65] & $\begin{array}{l}\text { Blackcurrant anthocyanin } \\
\text { concentrate }\end{array}$ & $3.6 \mathrm{mg} / \mathrm{kg}$ body weight & 1 dose & $\begin{array}{l}\uparrow \text { Serum antioxidant capacity } \\
\text { (chemiluminescence system) }\end{array}$ \\
\hline Healthy volunteers [66] & $\begin{array}{l}\text { Freeze-dried blueberry } \\
\text { powder }\end{array}$ & 1200 & 1 dose & $\begin{array}{l}\uparrow \text { Serum antioxidant capacity }\left(\mathrm{OCAR}^{*} \text {, }\right. \\
\left.\text { TAS }^{*}\right)\end{array}$ \\
\hline Healthy volunteers [67] & Strawberries & Not reported & 1 dose & $\downarrow$ Urinary NDMA \\
\hline Healthy volunteers [68] & Anthocyanin rich juice & 69 (daily) & 2 & $\begin{array}{l}\leftrightarrow \text { Plasma antioxidant capacity (FRAP) } \\
\downarrow \text { Plasma malondialdehyde }\end{array}$ \\
\hline \multirow[t]{2}{*}{ Healthy volunteers [69] } & Blackcurrant juice & 285-600 (daily) & 3 & $\begin{array}{l}\downarrow \text { Oxidative DNA damage MNBCs (Fpg } \\
\text { sites) } \\
\leftrightarrow \text { Oxidative DNA damage MNBCs } \\
\text { (strand breaks, endo III sites) }\end{array}$ \\
\hline & $\begin{array}{l}\text { Blackcurrant anthocyanin } \\
\text { concentrate }\end{array}$ & 285-600 (daily) & 3 & $\begin{array}{l}\leftrightarrow \text { Oxidative DNA damage MNBCs } \\
\text { (strand breaks, Fpg sites, endo III sites) }\end{array}$ \\
\hline
\end{tabular}




\begin{tabular}{|c|c|c|c|c|}
\hline Healthy volunteers [70] & Blood orange juice & 28 (daily) & 3 & $\begin{array}{l}\leftrightarrow \text { Plasma antioxidant capacity (mequiv of } \\
\text { uric acid) } \\
\leftrightarrow \text { Plasma malondialdehyde } \\
\leftrightarrow \text { Urinary 11-dehydro- } \mathrm{TB}_{2} \\
\uparrow \text { Lymphocyte resistance to oxidative } \\
\text { DNA damage }\end{array}$ \\
\hline Healthy volunteers [71] & Mixed fruit juice & 139 (daily) & 3 & $\begin{array}{l}\downarrow \text { DNA damage in MNBCs (comet assay) } \\
\leftrightarrow \text { Plasma malondialdehyde } \\
\uparrow \text { Glutathione status }\end{array}$ \\
\hline Healthy volunteers [72] & Cranberry juice & 2.1 (daily) & 2 & $\begin{array}{l}\leftrightarrow \text { Plasma antioxidant capacity (FRAP, } \\
\text { ESR) } \\
\leftrightarrow \text { Lymphocyte DNA damage (strand } \\
\text { breaks, oxidised pyrimidines) } \\
\leftrightarrow \text { Lymphocyte resistance to oxidative } \\
\text { DNA damage } \\
\leftrightarrow \text { Urinary 8-oxo-dG }\end{array}$ \\
\hline $\begin{array}{l}\text { Premalignant oral lesions } \\
\text { [22] }\end{array}$ & $\begin{array}{l}\text { Freeze-dried black } \\
\text { raspberry gel }\end{array}$ & Not reported & 6 & $\begin{array}{l}\downarrow \text { Lesional grade in } 41 \% \text { of subjects } \\
\downarrow \text { LOH at tumour suppressor gene- } \\
\text { associated loci }\end{array}$ \\
\hline $\begin{array}{l}\text { Premalignant oral lesions } \\
\text { [75] }\end{array}$ & $\begin{array}{l}\text { Freeze-dried black } \\
\text { raspberry gel }\end{array}$ & Not reported & 6 & $\begin{array}{l}\downarrow \text { Epithelial COX-2 } \\
\downarrow \text { Epithelial iNOS } \\
\downarrow \text { Microvessel density in a subset of } \\
\text { patients }\end{array}$ \\
\hline
\end{tabular}




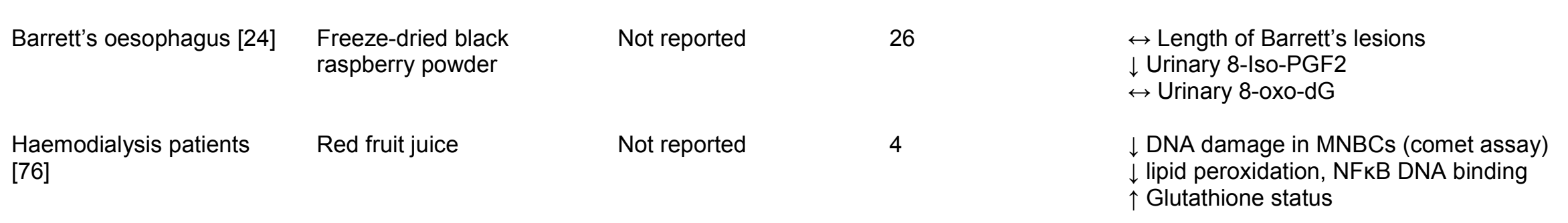

8-Iso-PGF2, 8-epi-prostaglandin F2a; 8-oxo-dG, 8-hydroxyguanosine; 11-dehyro-TXB 2 , 11-dehydrothromboxane $\mathrm{B}_{2}$; CAP-e, cell-based antioxidant protection assay; COX-2, cyclooxygenase-2; Endo III, endonuclease III; ESR, electron spin resonance; Fpg, formamidopyrimidine DNA

glycosylase; FRAP, ferric reducing ability assay; i-NOS, inducible nitrogen oxide; LOH, loss of heterozygosity; MNBCs, mononuclear blood cells; NDMA, N-nitrosdimethylamine; ORAC, oxygen radical absorbance assay; TAS, total antioxidant status; TEAC, Trolox equivalent antioxidant capacity assay.

*Unless specified otherwise. Statistically significant $(p<0.05)$ at ${ }^{\dagger}$ certain time points. $\diamond$ Not statistically significant.

$\uparrow$ Increase, $\downarrow$ Decrease, $\leftrightarrow$ Unchanged. 
Fig. 1

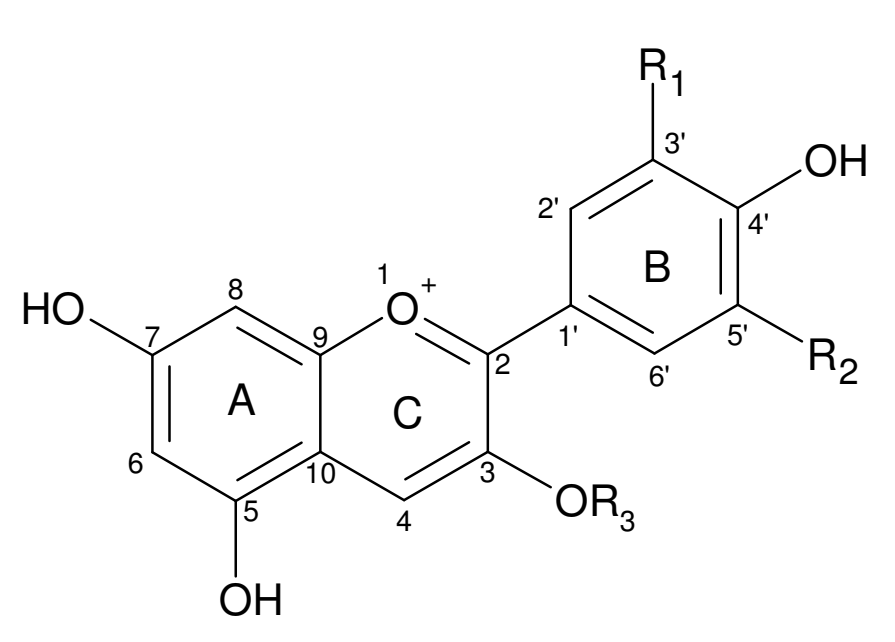

Cyanidin $\quad \mathrm{R}_{1}=\mathrm{OH}, \mathrm{R}_{2}=\mathrm{H}$

Delphinidin $\mathrm{R}_{1}=\mathrm{OH}, \mathrm{R}_{2}=\mathrm{OH}$

Petunidin $\mathrm{R}_{1}=\mathrm{OCH}_{3}, \mathrm{R}_{2}=\mathrm{OH}$

Peonidin $\quad \mathrm{R}_{1}=\mathrm{OCH}_{3}, \mathrm{R}_{2}=\mathrm{H}$

Malvidin $\quad R_{1}=\mathrm{OCH}_{3} \mathrm{R}_{2}=\mathrm{OCH}_{3}$

$R_{3}=$ Glucose, galactose or arabinose 
Fig. 2

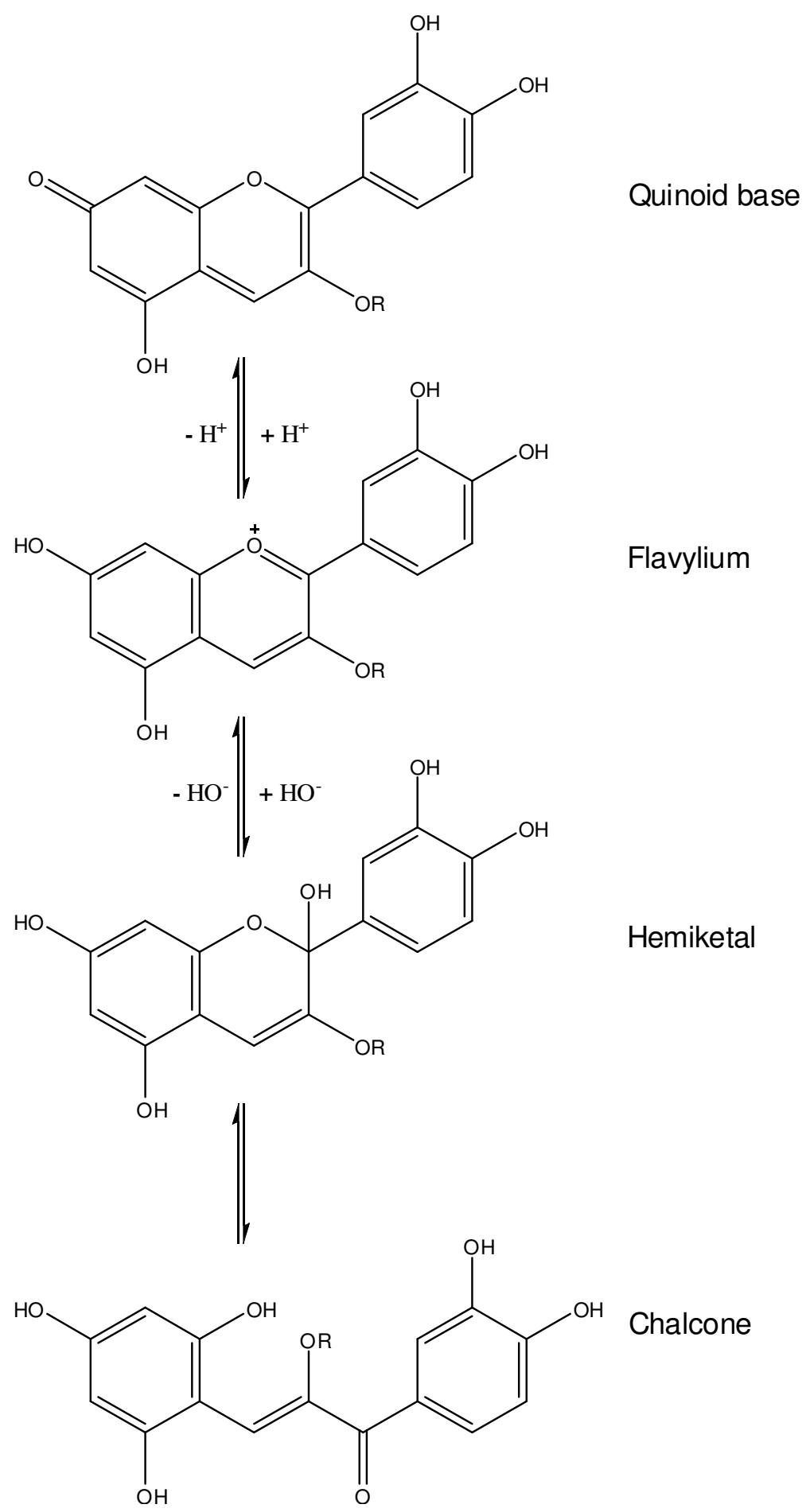


Fig. 1

B<smiles>C=C=C=C</smiles><smiles>O=Cc1c(O)cc(O)cc1O</smiles>

Phloroglucinol aldehyde Protocatechuic acid 